multiplication véritable de ces derniers microbes. Leur présence s'explique parce que le bacille fusiforme, de même que d'autres microbes pathogènes, est un hôte normal de la bouche des sujets sains. Cette dernière remarque s'applique aux lésions ulcéreuses diverses de la bouche et du pharynx, qui peuvent tantôt montrer quelques bacilles fusiformes, tantôt être littéralement envahies secondairement par l'infection fuso-spirillaire.

Une mention spéciale doit être faite pour le diagnostic différentiel de mon angine avec le chancre syphilitique ou les syphilides ulcéreuses de l'amygdale. L'angine a bacilles fusiformes a certainement été, parfois, confondue avec la syphilis des amygdales. Il est à remarquer, d'ailleurs, que la tonsille sous-jacente a l'infection fuso-spirillaire est souvent congestionnée et d'une consistance assez dure, et l'on peut alors penser, en présence de l'ulcération et de l'adénite, qu'il s'agit d'un chancre syphilitique. Cependant cette dureté modérée de l'amygdale n'est pas constante et n'est jamais aussi nette que dans le chancre spécifique. Enfin l'examen bactériologique vient lever tous les doutes. Mais il est important de savoir que les lésions syphilitiques secondaires ou tertiaires peuvent être infectées secondairement par le bacille fusiforme et les spirilles; ces microbes semblent avoir une certaine prédilection pour les ulcérations syphilitiques du pharynx. Dans ces cas, il est plus difficile de reconnaître la nature syphilitique de l'ulcération, dissimulée sous la fausse membrane. Il faudra, naturellement, tenir compte des accidents simultanés d'origine spécifique : roséole, plaques muqueuses, alopécie. Dans la syphilis, les ganglions cervicaux sont tuméfiés en même temps que les ganglions sous-maxillaires. Enfin le traitement servira de "pierre de touche" ou de criterium essentiel. L'angine à bacilles fusiformes est guérie en quelques jours si l'on frictionne deux fois par jour la lésion avec un tampon imprégné de teinture d'iode. Ce traitement est sans effet s'il y a une lésion syphilitique sous-jacente. Inversement le mercure et l'iodure de potassium déterminent la guérison de l'ulcération syphilitique, même si elle est compliquée par l'infection fuso-spirillaire ; ce traitement n'amène, au contraire, aucune amélioration de l'angine que j'ai décrite.

Bibliographie.-Athanasiì : L'Angine Ulcéro-membraneuse à Bacilles Fusiformes de Vincent, Thèse de Paris, 1900. Auché: Destruction complète de la Luette par le Processus Vlcéreux de l'Angine de Vincent, Gazette Hebdomadaire des Sciences Médicales, Bordeaux, Novembre. 1903. Baron: Zur Kentniss der Angina Exsudativa Ulcerosa, Archiv für Kinderheilkunde, Band xxyv., H. 3, p. 151. Bayer: Ueber Archiv für Kinderheilkunde, Band xxxv, H. 3, p. 151. Bayer: Ueber
Vincentsche Angina, Centralblatt fïr Laryngologie, Band xviii.. p. 353. F. Beaudoin: Un Cas d'Angine de Vincent au Cours d'une Ŝyphilis primaire, La Touraine Médicale, 15 Juillet, 1901. Bernard : Angine de primaire, La Touraine Médicale, 15 Juillet, 1901. Bernard: Angine de befund bei Stomatitis Ulcerosa, Centralblatt für Bakteriologie, Abt. I. befund bei Stomatitis Ulcerosa, Centralblatt für Bakteriologie, Abt. I., Band xxiii.,p. 177. Bonnus et Deguy: Sur l'Angine de Vincent, Journal des Praticiens, 19 Mai, 1900. Bosquier: Poussees d'Angine Ulcéromembraneuse avec Bacilles Fusiformes de Vincent, Journal des Sciences Medicales de Lille, 1899, No. 18. E. Botella: Angine de Vincent et Chancre de l'Ampgdale, Bolletino de Laringologia, Madrid, 1903-1904. H. W. Bruce: On Vincent's Angina, THE LANCET, 16 Juillet, 1904, p. 135. Carnot et Fournier: Sur un Cas d'Angine de Vincent, Société de Biologie, 1901. Ohauffard: Traitement de l'Angine de Vincent par le Bleu de Méthylène, Société Médicale des Hôpitaux de Paris, 1901, 27 Déc.. p. 1375. Chavigny: L'Angine de Vincent, Indépendance Médicale, 1901. Conrad : Ueber den heutigen Stand der Kenntnisse der Vincentschen Angina,
Archiv für Laryngologie, Band xiv., p. 525. Costa : Sur la Contagjon de l'Angine de Vincent, La Presse Médicale, 16 Déc., 1903. Costard: De l'Amygdalite à Bacilles Fusiformes, ou Maladie de Vincent, Thèse de Paris, 1900. Darier : Stomatite de Vincent, Journal de Médecine Interne, Juillet, 1903. Dopter: Un Cas d'Angine à Bacilles Fusiformes de Vincent, La Presse Médicale, 1898, No. 66, p. 74; L'Angine de Vincent, Gazette des Hôpitaux, 8 et 10 Mai, 1902 ; Contagiosité de l'Angine à Bacilles Fusiformes, Société Médicale des Hôpitaux de Paris, 1902. Faranella : Dos formes, Societé Médicale des Hôpitaux de Paris, 1902. Faranella : Dos Casos de Angina de Vincent, Meric. Yy Cirurg., 1902, No. 30. Fischer: Angine a aacilles Fusiformes et Spirilles de Vineent. American Journal
of the Medical Sciences, 1903, pp. 438-43. Forcheimer: St. Paul of the Medical Sciences, 1903, pp. 438-43. Forcheimer : St. Paul Medical Journal, Juin, 1901 . Fotiades : Stomatite et Angine avec constatation du Médecine, 1899, No. 47. Freyche: Etude sur l'Angine diphtéroide de Mécécine, 1899, Nincent, Thèse de Toulouse, 1899. Gallois et et ulcéreuse de lincent, rhése de Toulouse, loss. Gallois et Vourcoux: Bacille Gräupner: Ueber Angina Diphterö̈des Miinchener Medicinische Wochenschrift, 1902 p. 727 Hecht: Fälle von Vincentscher Angina, Monatschrift fuir Ohrenheilikunde, 1901, No. 3. O. Hess : Die Angina Vincenti, Deutsche Medicinische Wochenschrift, 1903, No. 42, p. 749. Iwanoff: Ueber die Angina Vincenti, etc., Petersburger Medicinische Wochenschrift, 1902, p. 32 . Jacques: Angine de Vincent chez
l'Enfant, Revue Hebdomadaire. Juin, 1899. Jurgens: Berliner Klinische l'Enfant, Revue Hebrlomadaire, Juin, 1899. Jurgens: Berliner Klinische
Wochenschrift. 13 Juin, 1904 . Lümmerhirt: Zur Kasuistik der Angina Vincenti, sive Diphteroides, Deutsche Medicinische Wochenschrift, 1902, No. 25, p. 442. Lansac: Sur un Cas d'Angine de Vincent,
Société de Biologie, ler Juin, 1901. Lesueur: These de Paris, 1900. Letulle: Sur un Cas d'Angine de Vincent, La Presse Médicale, 29 Déc., 1900. Lichtwitz et Sabrazès: Bacilles Fusiformes de nationales de Laryngologie, Otologie, et Rbinologie, 1899, No. 3 Malherbe: Sur le Traitement de l'Angine de Vincent, Gazette Médicale de Nantes, 28 Juillet, 1902. Manicatide und Vranialici; Fall von Angina mit Spindelformigen Brcillen und Spirochäten (Vincent), Münchener Medicinische Wochenschrift, 1902, No. 16, p. 673. Marfan: Diagnostic de l'Angine diphtérique, Gazette des Hôpitaux, 21 Mars, 1903, No. 34. Mayer: Afrections of the Mouth and Throat associated with the Fusiform Bacillus and Spirillum of Vincent, American Journal of the Medical sur l'Angine do Vincent, Thase De Montigny: Recherches Maratte: L'Angine de Vincent, Médecine Moderne, 5 Juin, 1901. Nicolle: Angine Ulcéro-membraneuse à Bacilles Fusiformes et Spirilles (Angine de Vincent), Archives Provinciales de Médecine, 1899. Oberwinther: Ueber Angina Ulcerosa, Münchener Medicinische Wochenschrift, 1904, No. 11, p. 500. Panofi : Thèse de Nancy, 1899. Queyrat: Angine de Vincent, Société Médicale des Hôpitaux de Paris, 18 Nov., 1904, Janvier, 1905, et 3 Févr., 1905. Rispal : Angine Diphtéroïde à Bacilles Fusiformes et Spirilles de Vincent, La Presse Médicale, No. 95, p. 146, 1898. Royster: Ulcération de l'Amygdale avec Bacilles de Vincent, Archiv of Pediatrics, Août, 1903, No. 9. Sacquépée: Cinq Cas d'Angine à Bacilles Fusiformes de Vincent, Archives Internationales de Laryngologie, Otologie, et Rhinode Vincent, Archives Internationales de Laryngologie, Otologie, et Rhino-
logie, 1899. Salomon : Bakter. befund bei Stomatitis und Tonsillitis logie, 1899. Salomon: Bakter. befund bei Stomatitis und Tonsillitis
Ulcerosa, Deutsche Medicinische Wochenschrift, 1899, No. 19; Weitere Ucerosa, Deutsche Medicinische Wochenschrift, 1899, No. 19; Weitere
Mitteilungen iiber Spirochäten-bacillenangina, ibid., 1901, No. 34. Mitteilungen tiber Spirochäten-bacillenangina, ibid., 1901, No. 34. Schneider: Angine à Bacilles Fusiformes de Vincent, La Presse
Médicale, $17 \mathrm{Juin}, 1899$. Silberschmidt: Ueber d. befund von SpiessMédicale, $17 \mathrm{Juin}, 1899$. Silberschmidt: Ueber d. befund von Spiesseinem Oberschenkelabscess, Centralblatt fuir Bakteriologie, Band xxx., einem Oberschenkelabscess, Centralblatt fuir Bakteriologie, Band xxx., leur pathogénie, Société Médicale des Hôpitaux de Paris, 6 Déc., 1901. Siredey : Un Cas d'Angine de Vincent, Société Médicale des Hôpitaux de Siredey: Un Cas d'Angine de Vincent, Société Médicale des Hôpitaux de
Paris, 25 Oct., 1901. Siredey et Mantoux. Stomatite de Vincent, La Paris, 25 Oct., 1901. Siredey et Mantoux : Stomatite de Vincent, La
Parole Mars, 1902, No. 3. Smirnoff : Ein Fall von Uleeröser Angina mit Vincentschen Bacillen, Medizinskoie Obosrenie, 1902, №. 4. Sobel and Herrmann: Uleero-membranous Angina with the Fusiform Bacillus (Vincent), a report of 12 cases in children, New York Medical Journal, vol. lxxiv., 1901, p. 1037. Speranski : Ein Fall von Ulceróser Angina mit Vincentschen Bacillen, Die Medicinische Woche, 1901, No. 16, p. 173. De Soecklin: Archives de Médecine Expérimentale, ler Mai p. 269, et Centralblatt fïr Bakteriologie, Abt. 1, Band xxiv., p. 612. Stolkind: Vier Fälle von Ulceröser Vincentscher Surmont: La Stomatite Clcéreuse, ses Rapports achenschrift, 1903 Vincent. Echo Médical du Nord, 6 Janv., 1901. Tarassewitch Ueber Vincentsche Angina, Russisches Archiv fiur Bakteriologie und Pathologie. Tobben: Angine de Vincent, Berliner Klinische Wochenschrift, 23 Mai, 1904 . Tscherno Schwarz: Ein Fall von Wochenschrift, 23 Mai, 1904. Tscherno Schwarz: Ein Fall von
Angina Vincenti, ref. Petersburger Medicinische Wochenschrift, Angina Vincenti, ref. Petersburger Medicinische Wochenschrift,
1903 , p. 76. Vigdortchik: Wratch Gaz. St. Petersb., 1901, viii., p. 689. H. Vincent : Sur l'Etiologie et sur les Lésions Anatomo-patbologiques de la Pourriture d'Hôpital (avec mention de l'angine à bacilles fusiformes et description de son microbe), Annales de l'Institut Pasteur. Oct., 1896, p. 492 ; Sur une Forme particulière d'Angine Diphtéroid (angine à bacilles fusiformes), Société Médicale des Hôpitaux de Paris, 11 Mars, 1898; La Presse Médicale, 12 Mars, 1898; Nouvelles Recherches sur l'Angine à Bacilles Fusiformes, Sociéte Médicale des
Hôpitaux de Paris, 13 Janv., 1899, et Archives Internationales de Hôpitaux de Paris, 13 Janv., 1899, et Archives Internationales do
Laryngologie, Otologie et Rhinologie. Mars, 1899; Cas prolongé d'Angine a Spirilles et Bacilles Fusiformes, Société Médicale des Hôpitaux de Paris ler Févr., 1901 ; Recherches Bactériologiques sur l'Angine à Bacilles Fusiformes, Annales de l'Institut Pasteur, 2 Août, 1899; Sur la Culture et l'Inoculation du Bacille Fusiforme, Société de Biologie, 23 Mars, 1901; Syphilis et Bacille Fusiforme, La Presse Médicale, 1er Juin, 1901; Sur un Cas de contagion de l'Angine à Spirilles et Bacilles Fusiformes, Société Médicale des Hôpitaux de Paris, 2 Mai, 1902; Diphtérie et Bacille Fusiforme, Société Médicale des Hôpitaux de Paris, Biologie, Jur la nature de la stomatite Ulcéro-membranense primitive Etude clinique et bactériologique Archives Internationales de Iaryngologie, Otologie, bacteriologique Archives internationale l'Angine à Bacilles Fusiformes, Question de priorité, ibic. Apropos 1905. Inoculabilité du Bacille Fusiforme au sujet Sain, Société Mádica. des Hôpitaux de Paris (Discussion), 10 Févr., 1905; Sur la Non-identité des Hopitaux de Paris (Discussion), 10 Fevrr., 1905; Sur lá Non-identite 18 Mars, 1905: Fréquence comparée de l'Angine à Bacilles Fusiformes. 18 Mars, 1905; Fréquence comparée de l'Angine à Bacilles Fusiformes,
La Presse Médicale, 29 Mars, 1905 . Widal et Darré: Angine de Vincent La Presse Medicale, 29 Mars, 1905. Widal et Darré: Angine de Vincent Paris, 18 Nov. 1904, et Archives Internationales de Laryngologie, Otologie, et Rhinologie, 1905, p. 51. Zwillinger: Ein Fall von Ulceröser Vincentschen Tonsillitis, Soc. Rhino-Laryngologique Hongroise, 23 Nov., 1904

Val de Grâce, Paris.

\section{TREATMENT OF COMPLETE UTERINE AND VAGINAL PROLAPSE. ${ }^{1}$}

BY FREDERICK HOLME WIGGIN, M.D.,

FORMERLY VICE-PRESIDENT OF THE AMERTOAN MEDICAI ASSOCIATION AND PRESIDENT OF THE NEW YORK STA'LE MEDICAL ASSOCIATION;

FELLOW OF THE NEW YORK ACADEMY OF MEDICINE; VISITIN

COLOGIST To ST. ELIZABETH's HOSPITAI, ETC.

So much diversity of opinion still exists among gynecic surgeons as to the proper treatment to be employed for the cure of complete uterine and vaginal prolapse that it seems timely again to bring this subject forward for discussion; and for this reason $\mathrm{I}$ desire to place before you for consideration the method of treatment which in my experience has proved the most satisfactory. Before

1 A paper read at the annual meeting of the American Medical Association, held at Atlantic City, N.J., on June 9th, 1904, before the Section on Obstetrics and Diseases of Women, 
doing this, however, a few words in regard to the pathology of the disorder may be of interest. The condition is best described as a reducible hernia through the pelvic floor, the sac being the inverted vagina, containing, besides the uterus, the tubes, the ovaries, the bladder, and the rectum, a large portion of the small intestines. The causation of the disorder, as is well known, is primarily a separation-often submucous-of the tendons of the muscles forming the pelvic floor where they unite in the median line and is usually due to the passage of the child's head during parturition. This separation of the tissues, which hold the rectum in its proper position, allows the lower anterior portion of the gut to bulge upward and forward into the vagina, pushing the vaginal tissues before it. This abnormal position of the buwel is increased by every act of defæcation and straining at stool and is also added to by the lifting of heavy weights. As the muscular force employed follows the line of least resistance it tends in these cases not to expel the lowel contents through the anus, as it should, but instead to force the gut forward through the hernial opening into the vagina. The difficulty experienced by the sufferer in emptying her rectum causes ler to exert an ever-increasing force and gradually and steadily, day by day, the rectocele increases in size, force in a downward direction being necessarily applied to the attached uterus and its ligaments, which in a normal condition serve simply as stays holding it in place, are gradualls stretched and lengthened, allowing greater freedom of position to the descending organ. As the uterus descends the bladder goes with it. The descending process is hastened, after it has fairly begun, by the added weight of the small intestines, which being contained largely in the pelvis find their way by gravity to the lowest point. Thus after a period of a longer or shorter duration, varying usually in accordance with the nat ural vigour of the patient and the amount and character of the work she is called upon by reason of her envircnment to perform, a complete inversion of the ragina occurs and a hernial sac of large size appears out-ide the body and we have the condition known as complete uterine and vaginal prolapse to deal with. This complete form of the disease does not, as a rule, appear until rather late in life, although the patient has probably suffered from much discomfort and disability for many years.

In the surgical treatment of this disorder much ingenuity has been displayed. Various operations on the anterior and posterior vaginal walls, as well as the removal of the uterus in whole or in part, have been re ommended, but unfortunately without very satisfactory results. In my opinion, these disappointing results have been due to the operator's failure in most instances to recognise the fact that the vaginal wall in these cases is a hernial sac with other contents than the uterus, tubes, ovaries, bladder and rectum, and that consequently the simple repair of the external perineal body, the removal of a larger or smaller portion of the vaginal walls, or even the removal of the uterus itself, would not correct the greatest cause of the difficultynamely, the abnormal position of the small intestines. In the elderly patients suffering from this disease who have come under my observation, many of them having external tumours of large size, the uterus has not been found abnormally enlarged and consequently could not be considered a factor in the causation of the trouble and many patients have come under observation upon whom a hysterectomy for the cure of this disorder had been previously performed by other surgeons who stated that their tumours were larger than before operation.

In view of the foregoing facts it seems clear that the operative procedures required for the successful treatment of the class of cases under consideration are those that will first obliterate the inverted and stretched vaginal wall-which is in reality a hernial sac-and then restore the damaged perineal structures and distended anterior raginal wall as nearly as possible to their normal condition. The technique which has, in my experience, best answered these requirements has been the following. The patient on coning under observation is placed in bed in the recumbent posture and the tumour is reduced, gruvity being employed to help retain the parts in their normal position by raising the foot of the bed about six inches. Tampons moistened with glycozone are placed in position and the parts treated until all the ulcerated portions of the vaginal walls have healed, the general condition of the patient being meanwhile carefully looked after. The next step in the procedure is the performance of a laparotomy after the usual preparations have been made, the patient being placed in the Trendelenburg posture before the abdomen is opened for the purpose of obtaining the aid of gravity in drawing the parts back into their normal position. The bowels are usually in these cases found to be more or less attached to tle vaginal wall by adhesions which must be broken up. 'T'he uterus, which, as has been previously stated, is in elderly women usually small, is found and pulled upward by the aid of bullet forceps, drawing the vaginal wall upward also. When this has been accompiished a needle armed with large size kangaroo tendon is passed through the fibres of the uterus at the point of its attachment to the round ligament and carried down the broad ligament in the form of a pursestring suture (see Fig. 1) and back again, the needle being

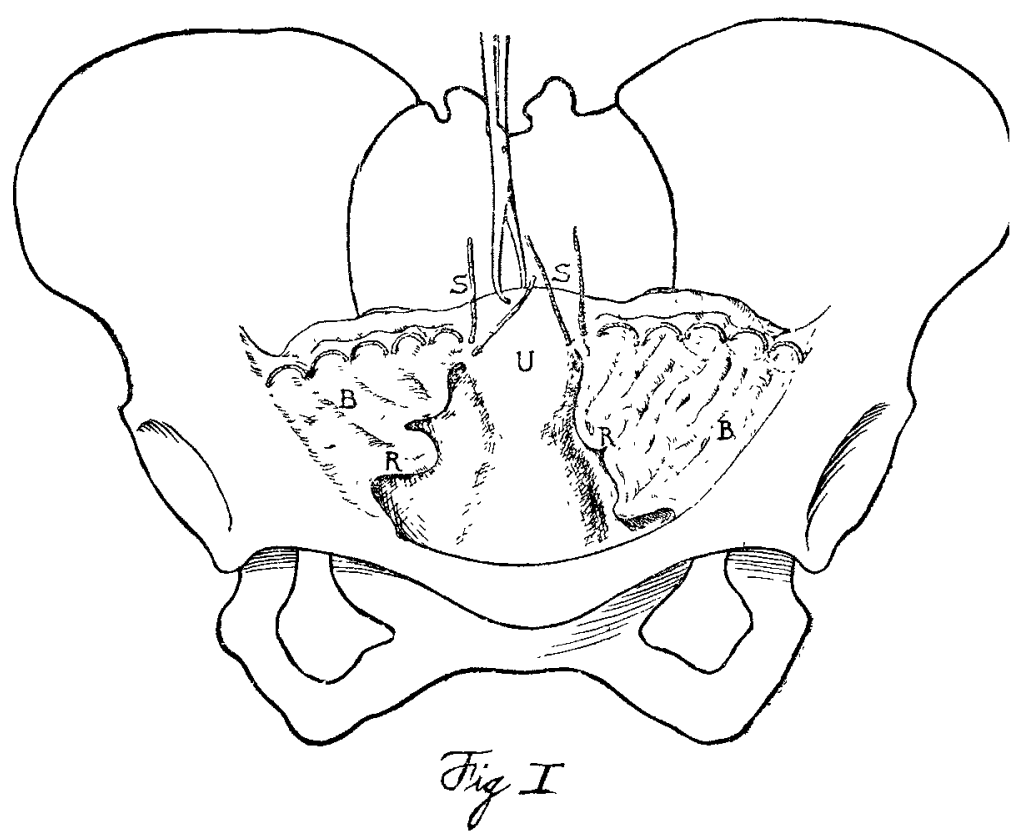

B B, Broad ligament. B R, Round ligament. S s, Sutures. U, Uterus.

finally made to emerge at about the point of entrance, so that when the two ends of the suture are drawn upon the broad ligament on that side is folded up and drawn together, thus doing away with its excessive length and giving the uterus a new point of attachment near the insertion of this ligament at the pelvic brim (see Fig. 2).

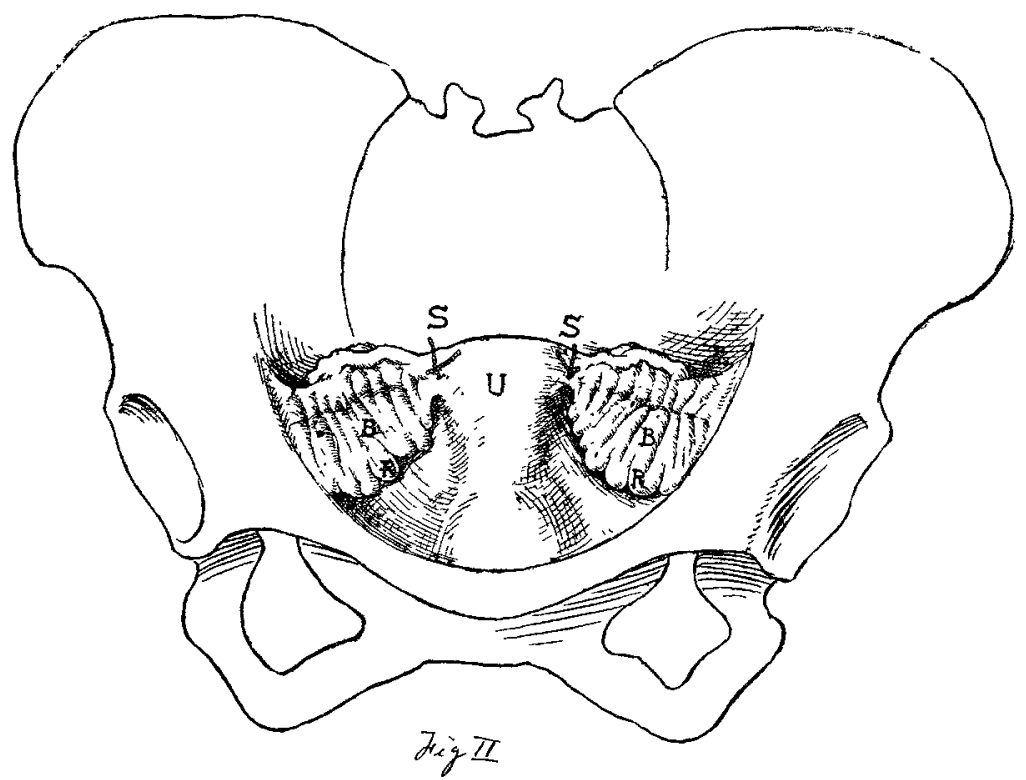

B B, Broad ligament. B R, Round ligament. s s, Sutures. U, L'terus.

The same process is repeated on the opposite side. The abdominal cavity is then flushed with saline solution, some of which is allowed to remain, and the wound in the abdominal wall is rapidly closed by means of buried sutures and protected by a celloidin clressing. If the patient is then in ordinarily good condition repair of the pelvic floor and reduction in size of the anterior vaginal wall are undertaken. In my experience there is usually no difficulty in accomplishing this, for all the operative measures necessary to 
make a complete cure can easily be performed in 40 minutes. In these operations time is an important factor, as most of the patients are elderly and do not bear prolonged operative procedures well, or those involving much loss of blood, heree the importance of not removing the uterus in whole or in part when it is not at fault in the treatment of this disorder. Many operations such as have just been described have been performed by me during the last few years on women whose ages ranged from 60 to 83 years, without mortality and with most satisfactory results.

New York City.

\section{CARCINOMA OF THE UTERUS AND ITS SURGICAL TREATMENT.}

BY EDWARD T. THRING, F.R.C.S. ENG., L.R.C.P. LOND. SURIFUN TO THE PRINCE ALFRED HOSPITAL, SYDNEY, ETC.

THE following brief notes of six cases of carcinoma of the uterus are given simply as examples of the method which, I believe, gives the best final result in those instances in which removal of the uterus is justified.

CASE 1.-The patient, a nullipara, married, aged 32 years, was first seen on Dec. 15th, 1894. She gave a history of repeated attacks of pelvic peritonitis, probably the result of an infective salpingitis. The menses had been regular every four weeks; of late there had been occasional blood-stained discharge between the periods. On examination the uterus was fixed and retroverted; both ovaries were cystic and of about the size of a large orange. From the posterior lip of the cervix was a fungating mass which bled readily on being touched. A portion removed for microscopic examination showed it to be carcinoma. Operation was performed on Dec. 24th. . The uterus, ovaries, Fallopian tubes, and broad igament were removed; also the pelvic glands. On section under the microscope two glands from the left side showed carcinomatous change. Five months after the operation a small recurrent nodule was excised from the scar in the vault of the vagina. There was no further recurrence. The patient is now (Feb. 4th, 1905) quite well.

CasE 2.-The patient, a nullipara, married, aged 50 years, was first seen on Feb. 16th, 1897. She complained of pain in the left side of the pelvis. The menopause took place three years and three months previously; "nothing seen" for two years and three months, then a "flooding" occurred and since then there had been slight irregular bleedings. Of late a bad-smelling discharge had been present. On examination the uterus was still of normal size-i.e., not atrophied; it occupied a good position, was tender to tonch, and slight bleeding occurred after examination. Operation was performed on March 19th. 'The uterus and appendages, together with the broad ligament and the - Jelvic glands, were removed. Two glands from the left side of the pelvis showed carcinomatous infiltration. This patient lived for six years well; she then became ill and died during the seventh sear from "Bright's disease." She was not nder my care at that time.

CASE 3 - The patient, married, aged 51 years, was first seen on August 12th, 1900. The menopause occurred seven \$ears previously. Three months previously a "sudden gush" of blood took place; slight bleeding had been present ever sine but no pain. On examination there was nothing abnormal in the thorax or abdomen. The uterus was of full size and not atrophied; there was an old cervical tear. The sound entered two and three-quarter inches, followed by blood from the os. Operation was performed on August 25th. The uterus and appendages, together with the broad ligament and the pelvic glands on both sides, were removed. The uterus showed carcinoma of the body growing from near whe right cornu; also two glands from the right side of the melvis were infiltrated by carcinomatous deposit. This patient is now (February, 1905) alive and well.

CASE 4. - The pitient, a multipara, married, aged 46 years, was first seen on March 14th, 1900. The menses had been regular every four weeks. She had had a "watery discharge "for nearly six months ; this was sometimes blood. stained. On examination a fungating ulcerated growth from the cervix was seen; this bled readily on being touched. The aterus was apparently free from adhesions. Operation was performed on March 21 st. The uterus and appendages, wogether with the broad ligament and the pelvic glands $\mathrm{cn}$ both sides, were removed. In this case there was carcinomatous infiltration of the glands from both the right and left sides, most marked, however, on the right. During the operation it was found to be easier to ligature the internal iliac artery of the right side than to reach the uterine artery far back ; this also allowed greater freedom in dissecting out the pelvic glands. On the fourth day there was a leakage of urine into the vagina, although a considerable amount was also drawn off through the urethra. This leakage gradually diminished and ceased entirely on the twelfth day. received a letter from this patient on Jan. 26th, 1905, in which she says that she is, and has been, perfectly well since her convalescence after the operation.

CASE 5:- The patient, a multipara, married, aged 33 years was first seen on July 1st, 1901. There was a history of severe bleeding from the vagina. The patient was blanched. On examination there was found a fungating growth from the cervix. This was removed with a sharp spoon to control the bleeding temporarily. Operation was performed on July 19th. The uterus and appendages, with the broad ligament and pelvic glands, were removed. The glands on the right side were infiltrated with carcinomatous deposit. The fungating mass was a cylindrical-celled carcinoma. The patient is now (February, 1905) well.

CASE 6.-The patient, a multipara, married, aged 34 years, was first seen on Jan. 2nd, 1903. The menses had been regular every four weeks up to August, 1902, then "floodings" occurred at each period, also some bleeding between times. The patient was blanched and breathless. On examination a fungating bleeding growth from the cervix uteri could be seen. On bimanual examination a gland on the left side of the pelvis, of the size of a pigeon's egg, slightly moveable, could be felt. Operation was performed on Jan. 14th The uterus and appendages, broad ligament, and pelvic glands were removed. The glands on both sides were infiltrated by carcinomatous deposit; this was more advanced in those of the left side. The patient when last seen a short time ago was well and there were no physical signs of recurrence.

I have given the above brief notes of these six instances of carcinoma of the uterus simply as illustrative cases. All occurred in my private practice and I was therefore able to follow them more closely than is usually possible in hospital practice. They are only a small number of those operated upon during the past ten years but they demonstrate the points which I wish to emphasise.

In each case the growth was examined microscopically. In each the pelvic glands were the seat of carcinomatous deposit secondary to the uterine growth. In one only could it be demonstrated before operation that there was involvement of pelvic glands-i.e., Case 6-the most recent one. The leakage of urine in Case 4 was, I believe, the result of trophic changes either in the base of the bladder or in the right ureter near the bladder and due to the fact that the right internal iliac artery itself was ligatured and not the anterior division of it or the uterine trunk. That there was no lesion at the operation is proved by the fact that there was no leakage until the fourth day after. I have seen this happen three times, and in each case the leakage only lasted a few days and ceased spontaneously, and in each of the three cases either the right or left internal iliac artery had been tied and divided. In two cases this was done to facilitate access to the deeper glands lying against the internal iliac vein. I have not met with any instance of septic cystitis spreading up along the ureters to the pelvis of the kidney, such as are recorded in the Johns Hopkins Hospital Bulletin for May, 1904. I think that this may be due to the fact that, recognising there must of necessity be a great deal of serous oozing after such an operation and also that, owing to the free removal of peritoneum, it is often difficult to obtain sufficient to cover over the exposed ureters and base of the bladder, I have made it a practice to pack the lower part of the pelvis lightly with a long strip of several thicknesses of iodoform gauze, bringing one end out into the vagina and so providing very free escape for the serum instead of the small drain which is apparently used at the Johns Hopkins Hospital in such cases.

The chief point, however, to which I desire to call attention is the fact that in all these cases the pelvic glands were more or less the seat of secondary carcinomatous deposit and that by no possibility could these glands have been removed had the ordinary vaginal operation of hysterectomy been performed. They can only be dissected out 